\title{
Entre a benção e a maldição: (re)açóes do catolicismo à modernização e modernidade europeia no século XIX
}

\author{
Robson Rodrigues Gomes Filho ${ }^{1 *}$ \\ ${ }^{1}$ Universidade Estadual de Goiás, Câmpus Morrinhos/GO - Brasil
}

\section{RESUMO}

A relação entre religião e modernidade tem sido já há algum tempo um alvo constante de reflexôes e debates. De modo geral, foi comum ao longo do século XIX a associação da religião católica àquilo que representava um passado a ser superado, de superstiçóes e crenças em um mundo encantado por intercessóes e milagres. Diante disso, a ambígua relação entre o catolicismo e o processo de modernização ocidental acaba por apresentar problemáticas importantes para se compreender o modo como a modernidade se consolidou no Ocidente. Em face disso, o presente artigo tem por propósito analisar as ambíguas reaçóes de setores da Igreja Católica europeia ao processo de modernização técnica e à consolidação da modernidade ao longo do século XIX, concentrando-nos de modo especial nos casos francês e alemão.

Palavras-chave: catolicismo; modernização; Europa; ultramontanismo.

\section{Between the blessing and the curse: (re)actions of Catholicism to modernization and European modernity in the 19th century}

\begin{abstract}
The relationship between religion and modernity has for some time been a constant focus of reflection and debate. In general, it was common throughout the 19th century to associate the Catholic religion with what represented a past to be overcome, made of superstitions and beliefs in a world enchanted by intercessions and miracles. In view of this, the ambiguous relationship between Catholicism and the process of Western modernization
\end{abstract}

DOI: http://dx.doi.org/10.1590/2237-101X02004212

Artigo recebido em $1^{\circ}$ de agosto de 2018 e aceito para publicação em $1^{\circ}$ de abril de 2019.

* Professor da Universidade Estadual de Goiás/Departamento de História/Programa de Pós-Graduação em História, Anápolis/GO - Brasil. E-mail: robson.gomes.filho@gmail.com. ORCID: https://orcid.org/00000002-9569-904X 
ends up presenting important questions for understanding the way in which modernity has consolidated in the West. The purpose of this article is thus to analyze the ambiguous reactions carried out by European Catholic Church sectors towards the process of technical modernization and consolidation of modernity throughout the 19th century. In order to do so, it focuses on the cases of France and Germany.

Keywords: catholicism; modernization; Europe; ultramontanism.

\section{Entre la bendición y la maldición: (re) acciones del catolicismo a la modernización y modernidad europea en el siglo XIX}

\section{RESUMEN}

La relación entre religión y modernidad ha sido desde hace algún tiempo objeto de reflexiones y debates. De modo general, fue común a lo largo del siglo XIX asociar la religión católica con lo que representaba un pasado a superar, de supersticiones y creencias en un mundo encantado por intercesiones y milagros. Delante de eso, la ambigua relación entre el catolicismo y el proceso de modernización occidental acaba por mostrar problemáticas importantes para comprenderse el modo como la modernidad se consolidó en Occidente. En frente de eso, el presente artículo tiene por propósito analizar las ambiguas reacciones de sectores de la Iglesia Católica europea al proceso de modernización técnica y consolidación de la modernidad a lo largo del siglo XIX, enfocándonos de modo especial en los casos francés y alemán.

Palabras clave: catolicismo; modernización; Europa; ultramontanismo.

Uma das associaçóes atuais mais comuns, no que tange ao surgimento cultural do capitalismo, em termos de causa e efeito, refere-se à possível ligação deste com a ética protestante. Tal associação se dá em razão da famosa obra de Max Weber, A ética protestante e o espírito do capitalismo, publicada em 1904 e 1905, cujo conteúdo nos leva a crer que o sistema capitalista moderno, seja cultural ou econômico, tem raiz diretamente ligada ao advento da ética protestante no século XVI. Assim, ao longo de todo o século XIX foi notória a afirmação de uma possível superioridade protestante ao catolicismo por conta de sua inegável alavanca à modernidade e ao progresso europeu e estadunidense.

No caso específico alemão foi comum, a partir da segunda metade do século XIX, a vinculação do catolicismo às massas ignorantes e supersticiosas, ao passo que o protestantismo (fundamentalmente liberal) representaria o progresso, a modernidade e o desenvolvimento 
nacional. Intelectuais consagrados na historiografia alemã, como Johann Gustav Droysen, afirmaram em diversas ocasióes que o catolicismo seria sinônimo de ignorância, submissão e cultura plebeia. Em carta a Heinrich von Sybel, em 1854, por exemplo, Droysen expressou que "quanto mais a sabedoria de nossos governos na Alemanha nos torna plebeus, maiores serão as perspectivas para a Igreja Romana". ${ }^{1}$ Dois anos antes, em 1852, o historiador escreveu ao seu irmão, Karl Droysen, que "este catolicismo pagão é mais adequado para as massas do que o protestantismo, que realmente exige de cada indivíduo uma melhora, uma elevação pessoal e enobrecimento". ${ }^{2}$

Esse tipo de associação, ainda comum ao longo do século XX, incomodou católicos dos mais variados setores, que viram em seu século uma importante alteração nesse cenário. Em sua própria obra de 1904/05, Weber admitiu que incomodava os setores católicos alemães a seguinte circunstância:

Uma simples olhada nas estatísticas ocupacionais de qualquer país que possua uma composição religiosa diversificada traz à tona com marcante frequência [...] o fato de que os líderes empresariais e detentores do capital, assim como os trabalhadores com maiores níveis de qualificação, e tanto mais o pessoal mais bem treinado técnica e comercialmente das empresas modernas, são, em esmagadora maioria, protestantes. $^{3}$

Tal incômodo, segundo nos parece, tem sua razão de ser. Nas primeiras décadas do século XX, após uma consolidação inegável do capitalismo enquanto sistema econômico e cultural, hegemônico em grande parte do ocidente, o catolicismo, não obstante seu retrocedente movimento ultramontano oitocentista, ${ }^{4}$ parecia, pelo menos em partes, adaptado a importantes mudanças culturais, econômicas e sociais que o mundo moderno lhe impunha. Não somente no uso parcialmente irrestrito de tecnologias, mas fundamentalmente na adaptação às novas condiçóes sociais e econômicas impostas pelo sistema industrial vigente, o catolicismo, como um todo, marchava no século XX, se não de mãos dadas, pelo menos enfileirado às rápidas transformações do mundo moderno.

\footnotetext{
${ }^{1}$ Johann Gustav Droysen to Heinrich von Sybel. 12 Dec. 1854, in Johann Gustav Droysen Briefwechsel. Ed. Rudolf Hübner (Stuttgart: Biblio-Verlag, 1967), 2: 300. Apud: GROSS, Michael. B. The war against catholicism: liberalism and the anti-catholic imagination in nineteenth-century Germany. Michigan: The University of Michigan Press, 2011, p. 97.

2 Johann Gustav Droysen to Karl Droysen, 17 sept. 1852, in Hübner. In: Johann Gustav Droysen Briefwechsel. Ed. Rudolf Hübner (Stuttgart: Biblio-Verlag, 1967), 2: 130. Apud: GROSS, Michael. B. The war against catholicism, op. cit., p. 109.

${ }^{3}$ WEBER, Max. The protestant ethic and the spirit of capitalism. New York: Charles Scribner's Sons, 1958, p. 33.

${ }^{4}$ Em linhas gerais, o movimento ultramontano pode ser descrito como "uma série de atitudes da Igreja Católica, num movimento de reação a algumas correntes teológicas e eclesiásticas, ao regalismo dos estados católicos, às novas tendências políticas desenvolvidas após a Revolução Francesa e à secularização da sociedade moderna." (SANTIROCCHI, Ítalo Domingos. Uma questão de revisão de conceitos: romanização ultramontanismo - reforma. Temporalidades, UFMG. v. 2, n. 2, ago/dez, 2010, p. 24).
} 
Para compreendermos as razóes dessa importante mudança de postura do catolicismo na passagem de um século para o outro, todavia, é necessário pensarmos de que maneira a Igreja Católica lidou, ao longo de todo o século 19, com os processos de modernização, industrialização e transformaçóes políticas na Europa, logrando ao século seguinte todo um campo de experiências para com as ideias de modernidade e progresso.

Interessa-nos, portanto, iniciarmos com a afirmação de que a relaçáo entre o catolicismo e o processo de consolidação da modernidade europeia (seja a partir das revoluçóes políticas, seja face à industrialização e modernização técnica) foi ambígua. Se, por um lado, é notório que "A Igreja Católica - não o catolicismo como um todo - constitui-se como uma instituição francamente reacionária a partir do Congresso de Viena", 5 por outro - especialmente no que tange à indústria, à inovação e à técnica - setores divergentes no mesmo seio do catolicismo, "em particular no episcopado, não economizaram elogios diante do novo mundo industrial: eles se uniam, na realidade, aos sentimentos dominantes na opiniáo esclarecida, marcada pelo saint-simonismo, dando-lhe uma evidente nota cristâ". ${ }^{6} \mathrm{Em}$ geral, é possível afirmarmos que "desenvolvia-se uma corrente que bendizia a mudança técnica em nome do cristianismo e lhe dava um conjunto de justificaçôes ideológicas apropriadas para vencer a eventuais reticências de populaçôes inquietas diante da novidade". ${ }^{7}$

Essa atitude ambígua do catolicismo nos remete ao fato de que, por mais que seja tentadora a tendência de se pensar a instituição como um todo, a verdade é que os sujeitos que ela compóem, especialmente quando pensados como frutos também de seus contextos históricos nacionais e regionais específicos, nem sempre comungam de suas posiçôes institucionais. Como nos alerta Jean Delumeau:

Náo se deve entáo projetar sobre este campo de atividade o julgamento que damos frequentemente à atitude romana diante do "modernismo". Em contrapartida, existe uma continuidade de Pio IX a Joáo Paulo II, passando por Pio XII: rigidez doutrinal, mas abertura às inovaçóes técnicas, desde que elas sirvam ao Homem. ${ }^{8}$

Esse posicionamento cristão face à novidade, ora de repulsa, ora de fascinação, todavia, é muito anterior aos séculos 19 e 20, podendo ser remetido, sem anacronismos, aos primórdios da Idade Média. Quintos Florens Tertuliano, apologista cristão dos primeiros séculos, afirmava que:

\footnotetext{
${ }^{5}$ MATA, Sérgio da. Entre Syllabus e Kulturkampf: revisitando o "reformismo" católico na Minas Gerais do Segundo Reinado. In: CHAVES, Cláudia M.; SILVEIRA, Marco A. (orgs.). Território, conflito e identidade. Belo Horizonte: Argvmentvm, 2007, p. 226.

${ }^{6}$ LAGRÉE, Michel. Religião e tecnologia: a bênção de Prometeu. Bauru (SP): EDUSC, 2012, p. 27.

${ }^{7}$ LAGRÉE, Michel. Religião e tecnologia: a bênção de Prometeu, op. cit., p. 58.

${ }^{8}$ DELUMEAU, Jean. Prefácio. In: LAGRÉE, Michel. Religiāo e tecnologia, op. cit., p. 15.
} 
O que o próprio Deus não produziu não lhe agrada. Vós direis que ele não teria podido ordenar as ovelhas a nascerem púrpura ou cor do céu? Se ele poderia e não o fez, é porque não o quis; o que Deus não quis, não se tem o direito de fabricar. O que não vem de Deus, autor da natureza, não é bom para a natureza. Logo, pode-se compreender que estas coisas vêm do diabo, o falsificador da natureza. ${ }^{9}$

Outros relevantes nomes da formação do cristianismo medieval declararam posicionamentos semelhantes. Santo Ambrósio, ainda no século IV da era atual, afirmava que "a agricultura era uma atividade nobre e divina, ao passo que o conatus iindustriae, o esforço de indústria, estava ligado ao pecado de Adão, do qual ele era finalmente mais a causa do que a consequência”. ${ }^{10}$ Por outro lado, nomes igualmente importantes para a formação do cristianismo adotaram posiçóes contrárias, marcando o contraste do debate muitos séculos antes do início e consolidação da modernidade na Europa. Santo Agostinho, por exemplo, em uma famosa passagem da sua Cidade de Deus, louvava o progresso das invençóes humanas, afirmando:

A que prodígios nos tecidos das vestimentas, na construção dos edifícios, a indústria humana chegou? Que progresso na agricultura, na navegação! Que imaginação, que perfeição nestes vasos de todas as formas, nesta multidão de estátuas e de quadros! [...] E tantas espécies de peixes, de armas e de máquinas inventados pelo homem contra o homem, tantos remédios e socorros chamados a defender e reparar a vida humana. ${ }^{11}$

São Tomás de Aquino, um dos mais influentes intelectuais formadores da doutrina católica, foi ainda mais longe ao afirmar que "a ação humana é uma imitação e, mais ainda, uma participação na atividade criadora de Deus" ${ }^{12}$ Essa ambiguidade católica face à atividade humana de criação logrou igual disparidade no século XIX, momento cuja quantidade, qualidade e velocidade invençóes industriais e técnicas não encontraram precedentes na história até então.

Em face disso, o presente artigo tem por propósito analisar as ambíguas reaçóes de setores da Igreja Católica europeia ao processo de modernização técnica e consolidação da modernidade ao longo do século XIX, focando-nos, de modo especial, nos casos francês e alemão. Não se pretende aqui, portanto, generalizar as perspectivas da Igreja Católica face

\footnotetext{
${ }^{9}$ TERTULIANO, Quintos Florens. De cultu feminarum: on the apparel of women. Disponível em: http:// www.documentacatholicaomnia.eu/03d/0160-0220,_Tertullianus,_De_Cultu_Feminarum_[Schaff], EN.pdf. Acesso em: 17 jan. 2019.

${ }^{10}$ LAGRÉE, Michel. Religião e tecnologia, op. cit., p. 41.

${ }^{11}$ AGOSTINHO, Santo. The city of God. V. III, book XXII, Chap. XXIV. Disponível em: http://www. documentacatholicaomnia.eu/03d/0354-0430,_Augustinus,_De_Civitate_Dei_Contra_Paganos,_EN.pdf. Acesso em: 17 jan. 2019.

${ }^{12}$ AQUINO, São Tomás de. Suma contra os gentios. Livro III. Porto Alegre: Editora da PUCRS, 1996, p. 409.
} 
à modernidade no século XIX, nem tampouco explorar as posiçôes oficiais da instituição romana por meio de seus documentos pontifícios. Antes, nossa pretensão é demonstrar as clivagens das reaçôes da Igreja Católica face ao mundo moderno tomando por objeto de análise dois países europeus de formação política e cultural distintas.

\section{"Praguejadores e turiferários": embates católicos face à modernização na França}

O termo "modernização", como variante da ideia de "modernidade", tem origem no bojo do processo de industrialização europeu no século XIX. Nesse sentido, modernizar-se está diretamente relacionado com a criação de condiçôes de inovação técnica que não apenas permita avanços do ponto de vista industrial, mas que também possibilite a comparação de si com uma condição anterior de "atraso", seja consigo mesmo, ou com seus pares, quando comparado com a condição presente; portanto, trata-se de uma categoria, antes de tudo, temporal. ${ }^{13}$

No caso do século XIX europeu, a ansiedade pela modernização e consequente progresso teve como efeito prático a criação das chamadas "Feiras Internacionais" ou "Exposiçôes Universais", cujas realizaçóes serviam, antes de tudo, para se medir o grau de desenvolvimento dos países nela envolvidos. De modo especial para a presente discussão, interessa-nos a realização da Exposição Universal de 1855, ocorrida em Paris.

Realizada no monumental Palais de l'Industrie et des Beaux-Arts, no coraçáo da Paris de Luís-Napoleão Bonaparte, a primeira Exposição Universal francesa, nominada Exposition Universelle des Produits de l'Agriculture, de l'Industrie et des Beaux Arts, reuniu mais de 5 milhões de espectadores e 34 países. ${ }^{14}$ Todavia, esse importante evento para a França oitocentista não teve, internamente, somente apoiadores. No âmbito religioso, especificamente, a clivagem mais explícita se deu entre ultramontanos, galicanos e liberais. Durante os preparativos para a Exposição, a imprensa francesa iniciou um acirrado debate em torno das relaçôes entre catolicismo e indústria, tendo como principais entusiastas os jornais: Le Siècle, de caráter republicano, liberal e anticlerical; Le Correspondant, de tendência católica, mas explicitamente ligado ao liberalismo; L’Ami de la Religion, editado por católicos galicanos; e L'Univers, católico de caráter explicitamente ultramontano. Segundo o historiador francês Michel Lagrée,

[...] a polêmica entre Le Sciècle e L'Univers se tornara, desde os anos 1850, um exercício quase cotidiano. Enquanto o jornal ultramontano náo perdia nenhuma oportunidade de fazer a apologia da tradição e da Idade Média cristá, com o triunfalismo consecutivo à publicaçấo

\footnotetext{
${ }^{13}$ KOSELLECK, Reinhart. Futuro passado: contribuição à semântica dos tempos históricos. Rio de Janeiro: Contraponto, 2012, p. 191-328.

${ }^{14}$ Sobre a Exposição de Paris de 1855, ver: LOPES, Ana Patrícia Quaresma. Exposiçóes universais parisienses oitocentistas. Coimbra: FCTUC, 2007.
} 
recente da encíclica Inter Multiplices sobre a Imaculada Conceição, o órgão liberal celebrava a modernidade sob todas as suas formas e fulminava a nostalgia dos séculos obscuros. ${ }^{15}$

Os embates entre os referidos jornais franceses ilustram de maneira bastante própria a relação dúbia entre a Igreja Católica e a industrialização europeia no século XIX na França. As tendências aqui representadas (liberalismo, catolicismo, galicanismo e ultramontanismo) são elucidativas dos conflitos ideológicos ocorridos tanto dentro do próprio ambiente católico, mais marcado pela divergência do que pela unidade, quanto entre a instituição católica e seus adversários externos.

O jornal Le Siècle, de tendência liberal, publicou, durante os preparativos da Exposição Universal de 1855, uma série de artigos expressando seu otimismo face à modernização europeia e seu louvor ao futuro que se abria no horizonte. De uma maneira geral, seus principais argumentos giravam em torno da 'grande festa do século XIX' como uma espécie de peregrinação que reunia os homens de boa vontade do mundo inteiro, levando a imaginar 'a santa aliança dos povos' sonhada pelo poeta". ${ }^{16}$ A vinda desses "peregrinos universais" seria facilitada pelo vapor, que abolira as distâncias e os perigos dos caminhos tão caros à época que o precedeu. Diante dessa 'reunião dos povos', cujo propósito seria a superação das diferenças sociais e religiosas, "quem podia ainda falar 'de católicos e protestantes, de cristãos e judeus, de muçulmanos e de bramanistas'? [...] O que se desenhava no horizonte da exposição universal era, de fato, o 'deus de Kant, deus das naçóes reunidas um dia, deus do progresso"”. ${ }^{17}$

Além do seu otimismo explícito, o jornal liberal não poupava críticas à imprensa católica, especialmente àquelas de tendência ultramontana. Sob a redação de Léon Plée, o periódico atacava o jornal L'Univers, já adiantando seus possíveis argumentos diante da Feira Mundial que se aproximava:

Eles vão dizer que nós tínhamos outrora a feira de Avignon e a de Bayone, a festa de São Cosme ou a fratria de São Landry, e para ali também se ia de mil pontos diferentes" [...] As feiras medievais não tinham nada a ver com as exposiçóes modernas: naquela época, as pessoas se reuniam por simples interesse comercial, com o objetivo de ludibriar e de "se enganar mutuamente. ${ }^{18}$

Já o periódico de tendência católica, mas liberal, Le Correspondant, publicava no mesmo período um conjunto de artigos de Alphonse Baudon sobre a atitude que os católicos deveriam tomar com relação à indústria. Segundo o editor francês, o "processo irresistível de

\footnotetext{
${ }^{15}$ LAGRÉE, Michel, Religiāo e tecnologia, op. it., p. 29.

${ }^{16} \mathrm{Idem}$.

${ }^{17}$ Idem.

${ }^{18}$ Ibidem, p. 30. 
difusão da indústria, outrora confinada à Inglaterra ou à Holanda, [...] até o presente, não chamou a atenção dos católicos". ${ }^{19}$ Como resultado, via-se que "há uma ou duas geraçôes, as naçôes protestantes 'triplicaram de importância', em contraste com a estagnação das naçôes católicas: França, Áustria, Espanha, Portugal”. ${ }^{20}$ Tal diagnóstico, para o catolicismo de tendência liberal, ilustrado pelo referido periódico francês, deveria servir não para uma atitude católica contra o processo de modernização liderado pelos países de maioria protestante. Antes, era preciso que os próprios católicos tomassem a dianteira do processo de industrialização e modernização da Europa, de modo a cumprirem um "dever moral" para com a sociedade moderna.

Segundo Baudon, editor dos referidos artigos publicados no Le Correspondant, "Por razóes morais, ligadas ao destino espiritual de milhôes de operários, os católicos não deviam, de forma alguma, desertar do campo da empresa industrial". ${ }^{21}$ A razão desse "dever moral" se dava à crença de que a indústria e suas zonas urbanas de trabalhadores estavam diretamente ligadas a "males bem conhecidos", como a miséria, bebedeira, doenças, suicídio, trabalho aos domingos, revolta, etc. Tais males não poderiam ser combatidos senáo pelo catolicismo, uma vez que o protestantismo (por sua suposta ilegitimidade religiosa) jamais seria capaz de exorcizar essas "enfermidades sociais". Além disso, era notório que as contribuiçôes financeiras dadas ao clero católico provinham de uma falida classe aristocrática fundiária, bem como das "classes inferiores, lá onde elas tinham a felicidade de continuar cristâs". ${ }^{22}$ Portanto, "o contraste era impressionante com a vizinha Inglaterra, onde os ambientes dos negócios mantinham eficazmente suas igrejas, suas escolas e suas missões". 23

Em face disso, o programa apresentado por Baudon para os católicos consistia basicamente em

[...] privilegiar sistematicamente as empresas que podiam mostrar sólidas referências cristấs, "como é notório que os protestantes fazem, entre eles, assim como os israelitas o fazem com seus correligionários". Enfim, garantir sua sucessão, formando seus filhos para ficar no mesmo estado e na mesma competência, ao invés de querer subir muito rápido. ${ }^{24}$

Por conseguinte, de um modo geral, o Le Correspondant ilustrava uma posição alternativa dentro do próprio seio do catolicismo francês adaptado e estribado no processo de modernização europeu. Além de asseverar as clivagens católicas face à indústria oitocentista, as posições

${ }^{19}$ BAUDON, Alphonse. Du progrès matériel et du renoncement chrétien. Le Correspondant, t. XXXIV, p. 675-97, 1854, e t. XXXV, p. 69-95, 1855; Les améliorations de la vie physique. AR, 9 jun. 1860. Apud: LAGRÉE, Michel. Religião e tecnologia, op. cit., p. 31.

${ }^{20}$ Ibidem, p. 30.

${ }^{21}$ Idem.

${ }^{22}$ Idem.

${ }^{23}$ LAGRÉE, Michel, Religiāo e tecnologia, op. cit., p. 31.

${ }^{24}$ Ibidem, p. 32. 
de Alphonse de Baudon indicam uma possibilidade para leitura do catolicismo do Oitocentos que foge às radicais oposiçóes ultramontanas e à modernizaçáo em curso no continente.

Ainda no âmbito dos embates da imprensa francesa à época da Exposição Universal de 1855 , as referidas posiçôes radicais ultramontanas podem ser visualizadas no jornal L'Univers. Fundado em 1833 pelo padre Jacques Paul Migne, o referido jornal católico se tornou amplamente conhecido na França, a partir da década de 1840, sob a direção do destacado ultramontano Louis Veuillot. Em linhas gerais, o L'Univers defendia a agricultura sobreposta à indústria, o campo sobre a cidade, o catolicismo sobre o protestantismo e a medievalidade sobre a modernidade. Sobre a suposta superioridade protestante em relaçáo aos católicos, no que tange ao progresso material, Veuillot defendia que a oposição do catolicismo à indústria era muito menos grave do que seu culto pelos protestantes. Ademais, alegava que a riqueza britânica advinha da estabilidade política, não do protestantismo, servindo o mesmo para os Estados Unidos da América, cujo potencial basear-se-ia somente na grandeza de seu território, ou mesmo a Prússia, que deteria o progresso material apenas por seu poderio militar; portanto, sem qualquer ligação estreita com sua maioria protestante. Já no que tange à argumentação do Le Correspondant sobre a necessidade de cristianizaçáo das indústrias, Veuillot não poupava palavras para contra-argumentar que

Os baixos salários e o trabalho infantil não dependiam "da má vontade dos chefes de usina. Eles também estão submetidos à lei da concorrência". A concorrência e todas as suas consequências evidentemente não existiam na época das corporações cristãs, ao passo que "a indústria aplica o princípio protestante: cada um por si”. A indústria não era má em si, e a Igreja a tomara sob sua proteção "em outros tempos [...], mas as condições da indústria mudaram; representando para todo católico um motivo de desconfiança." [...] Se os católicos queriam investir, era na agricultura que eles deveriam fazê-lo. ${ }^{25}$

Louis Veuillot representava, dessa forma, uma ala mais radicalmente contra a modernidade e modernização (ultramontanismo), especialmente quanto aos valores morais, cuja representatividade institucional acabou por ganhar mais força com os papas Gregório XVI e Pio IX ${ }^{26}$ Entretanto, as raízes dessa forma de tradicionalismo católico oitocentista, muito ligado às monarquias absolutistas e aos referenciais de uma nostalgia medieval como uma espécie de "paraíso perdido", podem ser encontradas ainda no final do século 18 em Louis-Gabriel-Ambroise, conhecido por Conde de Bonald.

Filósofo francês abertamente contrário ao Iluminismo, Louis de Bonald é considerado como o principal nome da intelectualidade católica da contrarrevoluçáo à época dos levantes

\footnotetext{
${ }^{25}$ Ibidem, p. 34.

${ }^{26}$ Sobre o pontificado de Gregório XVI e Pio IX, ver: AUBERT, Roger. Le pontificat de Pie IX (1846-1878). Paris: Bloud et Gay, 1952.
} 
franceses de 1789. Para Bonald, a promoção da indústria gerava inevitavelmente "o imenso ateliê das revoluçóes, que dá ocupação a toda a população industrial". ${ }^{27}$ Mais que isso, o filósofo católico argumentava que o processo de industrialização desumanizava os trabalhadores, condenados a se tornarem "apenas máquinas e cujo trabalho se limita a girar, durante a vida toda, uma manivela ou a mover um pêndulo". ${ }^{28}$ Esses argumentos se tornariam a base de uma série de "praguejadores contra a industrialização" (termo de Michel Lagrée) durante todo o século XIX, fundamentalmente ligados ao catolicismo ultramontano e à crítica aos valores modernos.

Dentre tais "praguejadores”, o próprio Louis Veuillot, editor do L'Univers, se destacou como uma das figuras ultramontanas mais eminentes da França oitocentista. Filho de artesão tanoeiro, consequentemente ligado a uma cultura técnica tradicional e avessa ao processo de mecanização, Veuillot desenvolveu uma verdadeira fobia contra toda forma de industrialização e modernização da Europa, chegando ao ponto de afirmar que "Eu preferiria a pena ou a matraca dos ínfimos ao transferidor e o compasso de nossos engenheiros" ${ }^{29}$

Em linhas gerais, a filosofia de Veuillot se desenvolveu sob três eixos: o atentado contra a natureza, o materialismo e a ameaça contra a liberdade. ${ }^{30}$ Em sua crítica à indústria, Veuillot argumentava que o papado nunca obrigaria seus súditos ao trabalho forçado nas minas e na manufatura, pois "por que ele os obrigaria a desenterrar o carvão e a respirar o algodão pulverizado se há os ingleses e franceses, protestantes e livre pensadores, que o fazem para beber aguardente?". ${ }^{31}$ Contra a ciência, seu argumento era de que o cientista "conhece e adora a Deusa-Indústria, o Deus-Vapor, a Deusa-Eletricidade [...] Eis seus deuses, seu culto, sua teologia, sua filosofia, sua política, sua moral, sua vida." ${ }^{32}$ Em resumo, Louis Veuillot cria que "ao invés de construir estradas de ferro, para ir sabe-se lá para onde, estradas canais, é preciso construir igrejas, evidenciá-las, restaurá-las, pois o templo cristão é o verdadeiro caminho que leva ao céu" ${ }^{33}$

\footnotetext{
${ }^{27}$ BONALD, M. de. Sur la mendicité. In: Oeuvres complètes de M. de Bonald. Tome III. Bruxelles: publié par la Société Nationale pour la Propagation des Bons Livres, 1845, p. 347. Disponível em: https:/gallica.bnf.fr/ ark:/12148/bpt6k234962?rk=42918;4. Acesso em: 17 jan. 2019.

${ }^{28}$ Sur les lettres, les sciences et les arts. In: BONALD, M. de. Oeuvres complètes de M. de Bonald, op. cit., p. 162.

${ }^{29}$ VEUILLOT, Louis. Le parfum de Rome. Tome 1. Paris: Edité par Gaume Frères et J. Duprey, 1862, p.26.Disponívelem:https://gallica.bnf.fr/ark:/12148/bpt6k1063362/f1.item.r=pr\%C3\%A9f\%C3\%A9rerais. Acesso em:17 jan. 2019.

${ }^{30}$ LAGRÉE, Michel. Religião e tecnologia, op. cit., p. 48.

${ }^{31}$ VEUILLOT, Louis, Le parfum de Rome, op. cit. p. 219.

${ }^{32}$ GAUME, Jean-Joseph. Le Signe de la croix au XIX siècle. Paris: Bibliothèque Saint Libère, 2006, p. 59. Disponível em: http://jesusmarie.free.fr/mgr_gaume_le_signe_de_la_croix.pdf. Acesso em: 17 jan. 2019.

${ }_{33}$ Plans développés de sermons, discours, conférences et allocutions par l'abbé Combatot, publicadas por Monsenhor Ricard. Paris-Lyons: Delhomme e Briquet. T. I, p. 336. Apud: LAGRÉE, Michel. Religião e tecnologia, op. cit., p. 49-50.
} 
Esses característicos discursos de Louis Veuillot ilustram uma tendência que não se limitou somente à França, ou mesmo a poucos intelectuais e clérigos franceses. ${ }^{34}$ Em geral, é possível afirmar que a fobia à indústria, à modernização e à modernidade, com seus valores científicos, racionais e, sobretudo, protestantes, foi o estandarte de importante parcela do catolicismo mais institucionalizado da Europa, sobretudo a partir da ascensão de Giovanni Maria Mastai-Ferretti ao papado, sob a alcunha de Pio IX, e seus desdobramentos até o Concilio do Vaticano I, em 1869.

Todavia, durante o mesmo século XIX europeu, desenvolveram-se correntes também católicas que, ao contrário dos "praguejadores", bendiziam a inovação técnica, a indústria e a modernização como um todo, justificando-se a partir de argumentos que intentavam unir os princípios cristãos à nascente modernidade industrial europeia. Padres, bispos e clérigos de toda classe proferiram discursos dos mais diversos em apoio à indústria, bendizendo e abençoando máquinas, edifícios, pontes, trilhos, etc. Segundo Michel Lagrée, foi justamente no campo da "bênção" que os "turiferários" desenvolveram um vindouro caminho de conciliação entre o catolicismo e a inovação técnica. Para o historiador francês, portanto, "a benção parece ter conhecido, da Monarquia de Julho ao Segundo Império, uma espécie de época de ouro, [pois] a maioria das inauguraçôes oficiais possuía então cerimônias religiosas em geral acompanhadas de grande fausto" ${ }^{35}$

Dentre os muitos argumentos utilizados pelo clero que assim se posicionava, destacaram-se o uso e as adaptaçóes de textos bíblicos para a justificação das bênçãos sobre aparatos técnicos e industriais. A partir do Salmo 18, por exemplo, foi comum a vinculação da descrição do salmista à imagem da locomotiva. No referido texto bíblico, encontra-se a seguinte passagem: "E a terra balançou e tremeu/ as bases dos montes se abalaram, estremeceram com o furor dele/ De suas narinas subiu a fumaça e da boca um fogo voraz/ dela saíam brasas ardentes". ${ }^{36}$ A utilização forçosa de textos como esses estava direcionada, em primeiro lugar, à argumentação pela juventude e atualidade da Bíblia. Além disso, "aqueles monstros bíblicos revisitados eram então domados pelo esforço do homem. Podia-se, assim, passar à bênção em sentido amplo, isto é, a todas as formas de assunção da tecnologia". ${ }^{37}$

Por esse caminho, uma ala da Igreja Católica traçou processualmente uma verdadeira "teologia da modernidade industrial". ${ }^{38}$ Nela, uma série de discursos, bênçãos e liturgias emergiam diante da necessidade cada vez mais constante de respostas e adaptaçóes da ins-

\footnotetext{
${ }^{34}$ Outros importantes nomes da intelectualidade ultramontana se destacaram no século 19, em sua maioria sob a influência de Louis de Bonald e Louis Veuillot. Dentre eles, podemos ressaltar: Abade Arminjon e Monsenhor Berteaud (bispo de Tulle) na França; Juan Donoso Cortés, na Espanha; Jules-Paul Tardivel, nos Estados Unidos; e Giuseppe Giovanni Luigi Maria Enrico Lanza di Trabia-Branciforte (popularmente conhecido por "Lanza del Vasto") na Itália.

${ }^{35}$ LAGRÉE, Michel. Religião e tecnologia, op. cit., p. 59.

${ }^{36}$ Salmo 18 (17). Versículos 8-9. Bíblia sagrada. Edição Pastoral. Sáo Paulo: Editora Paulus, 1990, p. 686.

${ }^{37}$ LAGRÉE, Michel. Religiáo e tecnologia, op. cit., p. 64.

${ }^{38}$ Ibidem, p. 66.
} 
tituição ao mundo moderno que desabrochava no horizonte europeu. Dentre muitos argumentos teológicos que surgiram, destaca-se, por exemplo, o de que, sendo o ser humano imagem e semelhança do Criador, nada seria mais natural que ele assumisse também sua condição de demiurgo. Segundo Monsenhor Plantier, em sua instrução para a Quaresma de 1860, estávamos de fato em uma "segunda criação", que duplicava e ampliava a primeira. Agora, entretanto, Deus teria confiado à sua criatura a condição de criador. Sendo assim, o homem do século XIX acabava de "quebrar o lacre do livro da Criação: os metais e a energia arrancados das entranhas da terra, mais do que um simples tesouro, constituíam uma verdadeira 'revelaçáo', aumentando a glória do Operário Supremo". ${ }^{39}$

Esse modo de se enxergar a industrializaçáo e modernização da Europa não se restringiu somente a um grupo ou classe de clérigos. Casos atípicos como alguns ultramontanos (reconhecidamente mais moderados que o discurso geral) posicionaram-se também em louvor ao quadro que se esboçava, como os casos do Monsenhor Pie, de Poitiers, e do Abade Moigno. ${ }^{40}$ Entretanto, o fato é que a defesa desta "teologia da modernização" ficou a cargo de tendências católicas já historicamente reconhecidas na França por seu caráter independente dos posicionamentos da Santa Sé, como o caso do galicanismo, ${ }^{41}$ ou mesmo os setores religiosos influenciados pelo saint-simonismo. Em linhas gerais, seus argumentos giravam em torno de que "o cristianismo náo lança o anátema contra o progresso material" e que "Se deixássemos de lado os efeitos acidentais ou os abusos intrínsecos, a indústria era boa em si mesma, enquanto a vitória da inteligência sobre a matéria, da liberdade sobre a fatalidade das leis naturais". ${ }^{42}$ Mais que isso,

[...] a própria indústria era a lei do cristianismo, pois permitia que o homem tomasse cada vez mais posse da terra, segundo o princípio bíblico no Eclesiástico 17.3. A única limitaçáo era que o progresso técnico fosse controlado, observado pela religiáo, sob pena de cair na decadência e no materialismo: era necessário, segundo o princípio de Inácio de Loyola, que a matéria fosse submetida ao homem e o homem submetido a Deus. ${ }^{43}$

\footnotetext{
${ }^{39}$ PLANTIER, Monseigneur. Instruction, lettres pastorales et mandements Tome 1. Paris: EMM. Renault Libraire, 1867, p. 115. Disponível em: http:// www.liberius.net/livres/Instructions,_lettres_pastorales_et_ mandements_de_Mgr_Plantier_(tome_1)_000000284.pdf. Acesso em: 17 jan. 2019.

${ }^{40}$ Sobre os casos citados acima, ver: HERBERMANN, Charles G. The Catholic Encyclopedia: an international work of reference on the constitution, doctrine, discipline and history of the Catholic Church. New York: Catholic Way Publishing, 2014.

${ }^{41}$ Com sua origem na região da Gália, na França do século XVII, o galicanismo pode ser descrito como uma tendência à regionalização da autoridade católica, subordinando a Igreja local à autoridade secular. Sobre uma conceituaçáo e discussáo sobre o galicanismo, o ultramontanismo e demais tendências católicas no século XIX, ver: SILVA, Wilson Santana. Correntes ideológicas do século XIX e a religião. Fides Reformata. v. XVIII, n. 2, 2013.

${ }^{42}$ LAGRÉE, Michel. Religiāo e tecnologia, op. cit., p. 72.

${ }^{43} \mathrm{Idem}$.
} 
A partir dos referidos argumentos, é possível percebermos que, apesar do louvor e dedicação em se provar o valor da indústria e da modernização para o mundo que o século 19 inaugurava, era necessário que a matéria permanecesse submissa ao Homem, e esse ao próprio Deus. Ou seja, a preocupação com as consequências do próprio processo em si agudava-se à medida que a urbanização, a mecanização e o progresso técnico traziam consigo a intensificação do ritmo de trabalho, o agravamento dos conflitos sociais e, principalmente, a mentalidade técnica, vista como uma substituição da crença religiosa pela crença na própria humanidade criadora e autônoma em sua capacidade de lidar com os desafios impostos pelo futuro. Todavia, é necessário percebermos que,

No final das contas, mesmo que houvesse efetivamente um debate sobre as consequências da Revolução Industrial - o que dava lugar para a condenação, pelo catolicismo intransigente, dos excessos do liberalismo econômico - ninguém queria abandonar as locomotivas pelas diligências, ou a lâmpada de Edison pela lâmpada a óleo. Exceto, precisamente, como vimos, ali onde deviam inscrever-se os limites da mudança tecnológica, isto é, no altar do Santíssimo Sacramento, um espaço quase fora do tempo, codificado de $\mathrm{A}$ a $\mathrm{Z}$ por um sistema de referências puramente religiosas. É somente no espaço da Igreja templum, na contiguidade máxima com o sagrado, dos materiais à iluminaçáo, que se pode observar algo que se aparentava ao rigor da Halakhah judaica. Ainda seria possível chegar, neste terreno, a concessóes negociadas ou impostas pela força do uso. Para o resto, e é ali provavelmente que se pode marcar a maior diferença com o judaísmo ortodoxo, maior liberdade foi dada aos fiéis no uso das comodidades materiais da civilização industrial moderna. ${ }^{44}$

Portanto, é fundamental percebermos que, em face da modernidade técnica, a Igreja Católica francesa do século XIX se posicionou de maneira, no mínimo, ambígua. Se, por um lado, pareceu-lhe indispensável o combate de frente, cujo argumento voltava-se para a necessidade de impedimento de que o novo horizonte de expectativas eliminasse o espaço de experiências vastamente católico dos séculos anteriores, por outro, diversos setores do próprio catolicismo não se fizeram de rogados diante de cada novidade técnica, abençoando e se adaptando às transformaçóes que, de maneira otimista, pareciam carregar a Europa à sua sina: o progresso.

Tal ambiguidade, mais fruto da diversidade interna do catolicismo do que de incoerências teológicas, deve ser encarada, entretanto, como uma (re)ação católica à modernização. Quando pensamos na modernidade, como um processo mais amplo que, ao englobar as mudanças técnicas, engloba também as transformaçôes políticas, ideológicas e sociais, nos deparamos com um posicionamento mais homogêneo do catolicismo. Essa disparidade deve ser entendida não como um paradoxo interno, mas, principalmente, como a necessidade de

${ }^{44}$ Ibidem, p. 490. 
adaptação da instituição ao mundo prático em detrimento ao ideológico. De acordo com Michel Lagrée,

Enquanto a modernidade política e ideológica questionava diretamente, até em suas obras vivas, um catolicismo que a diabolizava transformando-a em modernismo, a modernidade técnica agia em sentido contrário. Não existia então nenhuma razão objetiva que impedisse a Igreja Católica de acompanhar, mesmo que fosse às vezes com atraso, como entre Gregório XVI e Pio IX, o nascimento do novo mundo tecnológico. ${ }^{45}$

É, portanto, na diferenciação entre a modernidade técnica (entendida como "modernização") e a modernidade política e ideológica que encontramos a ambiguidade do campo de experiências católico com o século XIX europeu. Se, por um lado, a condenação à modernidade, enquanto valores modernos, era uma necessidade face ao avanço do racionalismo, deísmo, maçonaria e protestantismo, por outro, a modernização se fazia como um processo quase que irresistível, a cuja adaptação e diálogo a Igreja Católica não pôde se esquivar. Assim, é justamente na dimensão da (con)fusão entre modernidade e modernização que pode ser localizado um misto de fascinação e hesitação católica diante da consolidação do mundo moderno europeu.

\section{Catolicismo vs. liberalismo: a peleja pela modernidade e nação na Alemanha}

Em termos sociais, o catolicismo na Alemanha até a metade do século XIX foi predominantemente rural. Essa situação se prolongou até o fim do século. ${ }^{46}$ Entretanto, a partir do avanço da urbanização e industrialização do centro-europeu de 1850 em diante, uma onda de migrantes da zona rural para a urbana reconfigurou o cenário social e religioso das cidades alemãs.

O resultado desse movimento migratório foi, portanto, o reforço de uma estratificação social, especialmente nas áreas urbanas, cujo caráter religioso destacava-se na própria divisão de classes. Em geral, mesmo nas áreas de maioria católica, a minoria protestante era desproporcionalmente burguesa, formada especialmente por comerciantes, industriais, burocratas e profissionais liberais. Em contrapartida, na classe trabalhadora, predominou a maioria católica, que, em geral, foi largamente confinada aos estratos mais baixos da população, trabalhando nas fábricas e minas como diaristas, ou, quando muito, como pequenos empresários independentes ou mestres de ofício.

\footnotetext{
${ }^{45}$ Idem.

${ }^{46}$ Em regiôes como a Renânia do Norte, segundo Jonathan Sperber, o percentual de católicos na população de áreas rurais chegava a 64,9\% em 1871 (SPERBER, Jonathan. Popular catholicism in nineteenth-century Germany. New Jersey: Princeton University Press 1984, p. 39).
} 
Essas novas configuraçóes sociais agravaram o clima de instabilidade que precedeu as revoluçôes de 1848 e 1849. Em geral, as notícias das revoltas de março de 1848 em Berlim, bem como a grave crise econômica e os avanços da crítica socialista e liberal-democrata sobre o sistema político vigente, geraram distúrbios sociais generalizados em diversos estados da Confederação Germânica. Diante desse clima de tensão social, cuja força braçal estava nas mãos sobretudo das massas populares (em sua maioria católicas), a Igreja romana ascendeu como o principal braço do Estado na contenção da instabilidade política e social na Alemanha. Para além das medidas políticas de contrarrevolução, o Estado Prussiano (que dividia a soberania sobre os estados da Confederaçấo com a monarquia católica da Áustria) enxergou na Igreja Católica ultramontana um importante aliado contra a agitação social das massas.

Com amplo apoio conquistado entre o clero secular e regular ao longo das décadas de 1830 e 1840, o ultramontanismo viu nas crises e revoltas do final da primeira metade do século XIX a oportunidade de galgar espaço junto ao Estado, tanto bávaro, quanto prussiano. Concomitantemente à Assembleia de Frankfurt, em novembro de 1848, onde o Rei Frederico Guilherme IV da Prússia debatia soluçôes junto aos liberais e democratas para as convulsóes sociais, os bispos e arcebispos das dioceses católicas alemãs se reuniam em Würzburg (a pouco mais de 100 quilômetros de Frankfurt) para avaliarem a situação dos estados confederados e planejarem uma contrarrevolução. ${ }^{47}$ Para os clérigos em Würzburg, ao final de seu encontro, as revoltas não eram fruto apenas de problemas políticos, econômicos e sociais, mas, sobretudo, "causa e efeito da falta de religião e moral que ameaçava tanto a Igreja quanto autoridade monárquica”. 48

O resultado, tanto da assembleia em Frankfurt quanto em Würzburg, foi uma contrarrevolução bem-sucedida que aplacou os ânimos políticos (com concessôes democráticas que, em última análise, em muito pouco alterava o regime de benefícios da nobreza) e populares, dando abertura real do Estado prussiano à ação ultramontana entre os fiéis católicos e não católicos. A vitória da contrarrevolução produziu uma aliança entre Igreja e Estado que durou pouco mais de uma década; o suficiente para uma transformação radical da influência católica tanto na população, quanto na política, algo que despertou a desconfiança e oposição declarada não só de liberais e democratas, mas do próprio Estado prussiano protestante, gerando o que, posteriormente, se tornaria conhecido como Kulturkampf.$^{49}$

\footnotetext{
${ }^{47}$ Sobre o papel da Igreja Católica como agente de contrarrevolução no século 19, ver: JAEGER, Karin. "Die Revolution von 1848 und die Stellung des Katholizismus zur Problem der Revolution". In: HUBER, Wolfgang; SCHWERDTFEBER, Johannes (orgs.). Kirche zwischen Krieg und Friede: Studien zur Geschichte der deutschen Protestantismus. Stuttgart: Ernst Klett Verlag, 1976.

${ }^{48}$ GROSS, Michael. B. The war against catholicism, op. cit., p. 30.

${ }^{49}$ É chamado de Kulturkampfo período entre as décadas de 1870 e 1890 em que o império recém-unificado da Alemanha decretou um conjunto de leis cerceando o catolicismo e seu envolvimento político. Sobre o Kulturkampf, ver: LILL, Rudolf. Der Kulturkampf in Preußen und im deutschen Reich (bis 1878). In: JEDIN, Hebert (org.). Handbuch der Kirchengeschichte. Freiburg im Breisgau: Herder, 1973.
} 
O discurso contrarrevolucionário da Igreja Católica consistiu basicamente na argumentação de que os verdadeiros responsáveis pelas convulsóes sociais eram os ideais modernos. Para os bispos católicos, "as pessoas tinham sido 'inebriadas' e 'confundidas', 'enfeitiçadas' e 'deslumbradas' por modernas e elegantes filosofias: o materialismo, racionalismo, liberalismo e democracia, todas propagadas por um número infinito de jornais anticristáos antissociais". ${ }^{50}$ Em correspondência a Maximiliano II (rei da Baviera que assumiu o trono após Luís I ter renunciado em seu favor, em 1848), o bispo de Speyer, Nikolaus von Weiss, argumentou, em julho de 1851, que

A crença em um Deus pessoal, criador e mantenedor de todas as coisas, foi frequente e sistematicamente minada e destruída por uma falsa filosofia. O cristianismo tem sido atacado em seus fundamentos mais profundos e perdeu sua influência sobre muitas almas [...] Com o enfraquecimento ou destruição de fé no cristianismo divinamente revelado, tanto a autoridade da Igreja, quanto a autoridade secular foram minadas. Ambos se sustentam sobre a autoridade e ordem de Deus. ${ }^{51}$

Em outra correspondência, um padre do baixo clero de Bonn relatou, em 28 de agosto de 1850, ao arcebispo de Colônia, Johannes von Geissel que "uma parte significativa da população, infelizmente [...] não foi poupada pelo espirito desta época, que se caracteriza como o inimigo da religiáo, da verdade, e da moral". ${ }^{52}$

Tal posição, evidentemente, não fora somente alemã. Desde a Mirari Vos de Gregório XVI, de agosto de 1832, a Igreja Católica Romana firmou-se abertamente como contrária à "ânsia de inovaçôes". ${ }^{53} \mathrm{Na}$ Alemanha, de maneira especial, a luta contra a modernidade se tornou o mote de um grupo politicamente conservador e socialmente sedento de controle sobre a autonomia religiosa de seus fiéis. Ao contrário, portanto, do catolicismo ilustrado do século anterior, o ultramontanismo caminhou na contramão de qualquer adaptação da Igreja ao mundo moderno e, para tanto, aproveitou-se do momento histórico oportuno de crise para garantir o apoio do Estado para uma ampliação vertiginosa de seu poder político e social na Europa central.

\footnotetext{
${ }^{50}$ GROSS, Michael. B. The war against catholicism, op. cit., p. 31.

${ }^{51}$ Bischof Nikilaus von Weis na den König Max von Bayern, Speyer, 24 July 1851, Aktenstücke, 72. Apud: GROSS, Michael. B. The war against catholicism, op. cit., 2011, p. 31.

${ }_{2}$ Pf. von Bonn na den Erzbischof Johannes von Geissel, 28 Aug. 1850, Aktenstücke, 34. Apud: GROSS, Michael. B. The war against catholicism, op. cit., 2011, p. 32. Grifo nosso.

${ }^{33}$ GREGÓRIO XVI, Papa. Mirari Vos: sobre os principais erros do seu tempo. MONTFORT Associação Cultural. Disponível em:

http://www.montfort.org.br/old/index.php?secao=documentos\&subsecao=enciclicas\&artigo=mirarivos. Acesso em: 17 jan. 2019.
} 
A nova aliança entre Igreja e Estado, de uma maneira geral, se deu de modo muito diferente daquela vivida no Reichskirche. ${ }^{54}$ No pós-1848 alemão, a Igreja Católica gozou de ampla liberdade em relação ao Estado, recebendo dele um vasto espaço de atuação em setores considerados decisivos para o impedimento de novas convulsóes sociais de cunho liberal, democrático ou socialista.

Desse modo, o movimento ultramontano na Alemanha, de uma maneira geral, teve seu principal momento de expansão e consolidaçấo a partir da década de 1850. Antes disso, porém, o ultramontanismo conquistou, desde o início do século, importante espaço já na formação de uma nova geraçáo de clérigos cada vez mais resoluta na necessidade da unificação católica sob a bandeira do papa, como resposta direta ao nacionalismo em escalada e aos valores modernos com ele ascendentes. Nesse contexto, se sobressalta a importante influência do chamado "Círculo de Mainz" [Mainzer Kreis], formado por importantes nomes do ultramontanismo alemão do início do século 19, como os bispos Andreas Räß, de Estrasburgo, Nikolaus von Weis, de Speyer, Joseph Ludwig Colmar, de Mainz, Johannes von Geissel, de Colônia, e o influente teólogo Bruno Franz Leopold Liebermann. ${ }^{55}$

O resultado em médio prazo da ascensão ultramontana na Alemanha foi o que a historiografia recente sobre o assunto chama de "reavivamento católico" [Katholische Erneuerung], que, na prática, consistiu em uma significativa clericalizaçáo do catolicismo alemão por meio da ação missionária sob os ideais do papismo ultramontano. ${ }^{56}$ Como consequência, esse expressivo reavivamento do catolicismo na Alemanha despertou a oposição de diferentes grupos, especialmente entre intelectuais liberais, democratas e socialistas, fossem eles maçons, protestantes ou, até mesmo, católicos simpatizantes do superado iluminismo católico do século anterior. ${ }^{57}$ As razóes para a oposição foram ora políticas, ora religiosas, mas - o que, para a presente reflexão, é mais importante - também estão essencialmente vinculadas à fundação e consolidação da modernidade e nação na Alemanha. Logo, impedir o avanço político e religioso do catolicismo era lutar pelo futuro democrático - ou liberal, ou protestante -, mas, antes de tudo, moderno da nação alemá.

\footnotetext{
${ }^{44}$ Por Reichskirche pode-se entender o longo período de cooperação entre Igreja e Estados católicos alemães que perdurou do início da era medieval até o início do século 19. Por meio desse regime político-religioso, a Igreja mantinha-se ligada ao Estado, cedendo-lhe grande interferência em seus assuntos internos enquanto recebia dele o apoio financeiro e a condição de nobreza para bispos e demais membros do alto clero. Sobre o assunto, ver: DECOT, Rolf. Säkularisation der Reichskirche 1803: aspeckte kirchlichen Umbruchs. Mainz, Philipp von Zabern, 2001.

55 Sobre as transformações no clero a partir de uma nova geração versada sobre o ultramontanismo, ver: ANDERSON, Margareth. Piety and politics: recent work on German catholicism. Journal of Modern History. n. 63, dec.1991, p. 697.

${ }^{56}$ Sobre o assunto, ver: ANDERSON Margareth. The limits of secularization: on the problem of the catholic revival in nineteenth-century Germany. Historical Journal. n. 38, 1995.

${ }^{57}$ Sobre o iluminismo católico na Alemanha, ver: PRINTY, Michael. Enlightenment and the creation of German catholicism. Cambridge University Press, 2009.
} 
A ascensão expressiva do número de monges, padres e freiras após 1850, bem como de romarias e demais demonstraçōes da piedade popular católica (considerada como símbolo de um "medievalismo" 58 e, por isso, avessa à modernidade racional e ilustrada proposta), gerou por parte da imprensa liberal uma campanha acirrada contra o catolicismo ultramontano na Alemanha. Os mais importantes jornais de linha liberal, ${ }^{59}$ existentes ou fundados a partir de 1850, disparavam matérias, reportagens ou ilustraçôes periódicas reforçando o caráter antimoderno do catolicismo e o perigo que ele representava para a nação alemã. Competindo diretamente com as açôes missionárias pela conquista e adesão de simpatizantes, tais periódicos lograram um alcance notável de assinaturas e leitores. Segundo os dados colhidos por Michel Gross, somente o Gartenlaube - jornal ilustrado de linha liberal fundado em 1853 - aumentou suas assinaturas "de 5.000 para náo menos de 100.000 em 1860, e em 1867 já tinha atingido mais de 225.000, uma estatística impressionante para os padróes do jornalismo meados do século". ${ }^{60}$

A ascensão política do liberalismo e dos ideais anticatólicos, no entanto, não teve grande relevância na Alemanha até 1858. A partir do verão daquele ano, o rei da Prússia, Frederico Guilherme IV, foi considerado irremediavelmente insano pelo Conselho Regente, sendo substituído por seu irmão, Guilherme I, que se tornaria rei a partir da morte do seu antecessor em 1861. Frederico Guilherme IV havia sido o monarca governante à época das agitaçôes revolucionárias de 1848 e 1849 e, por isso, fora um dos principais responsáveis políticos pela abertura ao catolicismo e demais açôes contrarrevolucionárias na Alemanha. Seu irmão, entretanto, ao assumir a regência dispensou os ministros reacionários e nomeou um novo ministério composto essencialmente por simpatizantes da oposição liberal. Essa mudança no cenário político iniciou uma nova era para a Igreja Católica na Alemanha, que passava gradualmente de braço do Estado contra o liberalismo revolucionário para um inimigo a ser vencido na luta pela nação e modernidade alemá.

\footnotetext{
${ }^{58} \mathrm{O}$ termo "medievalidade" ou "catolicismo medieval" [mittelalterlichen Katholizismus] empregado ao longo do presente artigo para se referir a determinadas características das práticas e religiosidade católicas se encontra em várias das bibliografias consultadas. Trata-se aqui de uma referência sobretudo temporal, empregada por sujeitos oitocentistas, que lança o modo de vida católico a um passado que se pretendia ser superado pela modernidade iluminista e liberal. Por essa razão, utilizaremos o referido termo entre aspas, como forma de expressarmos o aspecto singular que o vocábulo apresenta nesta discussão.

${ }^{59}$ Dentre os referidos periódicos, destacaram-se: Breslauer Zeitung, Crefelder Zeitung, Deutsche Allgemeine Zeitung, Kölnische Zeitung, National Zeitung, Vossische Zeitung, Frenzboten, Die Gegenwart, Preussische Jarhrbücher, Ulk, Berliner Wespen e Kladderadatsch, todos de cunho liberal, acadêmico, maçom ou protestante que reforçaram a campanha anticatólica ao longo de todo o século XIX e que culminou no Kulturkampf.

${ }^{60}$ GROSS, Michel B. The war against catholicism, op. cit., p. 136. Interessante notar que o mesmo uso da imprensa escrita foi feito pelos Redentoristas no século seguinte em campanhas de tom bastante semelhante contra o espiritismo, protestantismo e maçonaria em Goiás. Nos capítulos seguintes, retomaremos essa discussão para compararmos os periódicos a fim de discutirmos o espaço de experiências redentoristas formado a partir dos conflitos que debatemos no capítulo presente.
} 
No parlamento prussiano, no entanto, as tensóes entre a realeza e os ideais liberais se tornavam cada vez mais evidentes à medida que o liberalismo avançava politicamente e ameaçava a nobreza aristocrática. Embora tenha dado importante abertura ao liberalismo na política alemã, Guilherme I teve de enfrentar alguns anos depois a oposição do parlamento (cuja ampla maioria liberal foi eleita em 1861) a suas reformas no exército. Sem muitas saídas políticas, o rei prussiano nomeou o junker ${ }^{61}$ Otto von Bismarck para o cargo de primeiro-ministro, algo que repercutiu como conflito entre o ministério e o parlamento, mas como um problema ainda maior para os católicos, visto que Bismarck era declaradamente contra o domínio da Áustria católica sobre os reinos alemães, pondo fim à união entre o conservadorismo do Estado e a Igreja Católica na Alemanha. Em poucos anos, Bismarck conseguiu reunir em torno de si os interesses nacionalistas dos liberais e da aristocracia alemá, travando guerras pela expansão do domínio prussiano e configurando um inimigo interno cada vez mais necessário de ser ajustado ao futuro quisto para o império alemão: o catolicismo.

Contudo, não se trata aqui apenas de uma "guerra contra o catolicismo", como defende Michel Gross, ${ }^{62}$ mas de um conjunto de "guerras culturais e políticas" (perspectiva defendida por Christopher Clark e Wolfram Kaiser), ${ }^{63}$ das quais tanto o liberalismo protestante tomou parte contra o catolicismo e seu fundamentalismo institucional antimoderno, como a própria Igreja Católica travou inúmeras batalhas na defesa da legitimidade política e cultural do papa e do catolicismo, ou mesmo da manutenção da tradição em oposição à modernidade. Sendo assim, para nos utilizarmos das palavras de David Blackbourn, "o que estava claramente em jogo em ambos os lados era um modo de vida"64 no mundo moderno.

No âmbito político, a Igreja Católica conquistou até a metade da década de 1860 poucas vitórias contra liberais, especialmente face aos êxitos notáveis dos partidos progressistas nas eleiçôes entre 1861 e 1865, mesmo em áreas de predominância católica. Embora seja contraditório, tal comportamento dos eleitores católicos tem uma razão de ser: ainda que os partidos liberais e democratas se opusessem politicamente à Igreja Católica, eram os conservadores ligados a Bismarck e à política prussiana protestante contra a Áustria que preocupavam os eleitores católicos. A Igreja alemá, por conseguinte, se viu dividida entre um progressismo anticatólico e um conservadorismo essencialmente prussiano e protestante. Se, por um lado, o liberalismo era um inimigo declarado ao catolicismo, por outro "o conservadorismo protestante e o Estado prussiano não eram aliados mais confiáveis." ${ }^{65}$

\footnotetext{
${ }^{61}$ Junker é o termo utilizado para denominar a nobreza aristocrática prussiana no século XIX.

${ }^{62}$ GROSS, Michel B. The war against catholicism, op. cit.

${ }^{63}$ CLARK, Christopher; KAISER, Wolfram (orgs.). Culture wars: secular-catholic conflict in nineteenthcentury Europe. Cambridge: Cambridge University Press, 2003.

${ }^{64}$ BLACKBOURN, David. Progress and piety: liberalism, catholicism and the state in Imperial Germany. History Workshop Journal. n. 26, Autumn, 1988, p. 65.

${ }^{65}$ SPERBER, Jonathan. Popular catholicism in nineteenth-century Germany, op. cit., p. 153.
} 
Nesse sentido, apesar de uma era de ampla ascensão social e religiosa nas décadas de 1850 e 1860, a partir da ascensão de Bismarck e das oposiçóes políticas tanto de liberais, quanto de conservadores, somadas ao apoio prussiano à Itália liberal e à própria guerra contra a Áustria em 1866, a Igreja Católica entrou em um período de grave conflito na Alemanha. Seu resultado foi o Kulturkampf na década seguinte. Mas o caminho até lá foi calcado tanto por frequentes e intensos ataques católicos ao liberalismo, maçonaria e protestantismo - fundamentando-se especialmente no centralismo político e religioso em Roma -, quanto por uma intensa campanha anticatólica promovida pela imprensa liberal-protestante, cujos teor e argumento fundamentavam-se essencialmente na disputa pela modernidade e nação alemã contra o "medievalismo" e submissão papal do catolicismo ultramontano.

\section{Considerações finais}

O discurso ultramontano que garantiu à Igreja Católica uma ascensão política na Alemanha foi essencialmente um discurso antimoderno. Diferentemente do caso francês, portanto, o catolicismo ultramontano na Alemanha muito pouco se preocupou em se contrapor à dimensão técnica e tecnológica da modernidade. Nos estados alemães, a preocupação do clero católico era com o "espírito desta época", ${ }^{66}$ qual seja, os valores modernos em ascensão.

A razão dessa diferença reside, dentre outras coisas, no desenvolvimento histórico das transformaçôes técnicas, industriais e, especialmente, da ideia de nação em cada um dos lados. Diferentemente do caso francês, os componentes simbólicos, políticos e culturais de fundação da nação na Alemanha pesaram mais para a construção da modernidade alemã do que a industrializaçáo em si, uma vez que foram a tardia unificação dos reinos germânicos, por um lado, e os ideais liberais do que deveria ser um Estado e nação modernos, por outro, que deram o tom sobre a maneira como a cultura alemã deveria se firmar como identidade nacional e moderna. Tal processo, no entanto, deveria passar por uma luta não somente política, mas especialmente cultural, cujo alvo central - o catolicismo - representava o antigo regime político e a "medievalidade" que se almejava superar.

\section{Referências}

AGOSTINHO, Santo. The city of God. v. III, book XXII, chap. XXIV.

Disponível em: http://www.documentacatholicaomnia.eu/03d/0354-0430,_Augustinus,_ De_Civitate_Dei_Contra_Paganos,_EN.pdf. Acesso em: 17 jan. 2019.

\footnotetext{
${ }^{66}$ Pf. von Bonn na den Erzbischof Johannes von Geissel, 28 Aug. 1850, Aktenstücke, 34. Apud: GROSS, Michael. B. The war against catholicism, op. cit., p. 32.
} 
ANDERSON Margareth. The limits of secularization: on the problem of the catholic revival in nineteenth-century Germany. Historical Journal. n. 38, 1995.

ANDERSON, Margareth. Piety and politics: recent work on German catholicism. Journal of Modern History. n. 63, dec. 1991.

AQUINO, São Tomás de. Suma contra os gentios. Livro III. Porto Alegre: Editora da PUCRS, 1996.

AUBERT, Roger. Le pontificat de Pie IX (1846-1878). Paris: Bloud et Gay, 1952.

BLACKBOURN, David. Progress and piety: liberalism, catholicism and the state in Imperial Germany. History Workshop Journal. n. 26, Autumn, 1988.

BONALD, M. de. Sur la mendicité. In: Oeuvres complètes de M. de Bonald. Tome III. Bruxelles: publié par la Société Nationale pour la Propagation des Bons Livres, 1845, p. 347. Disponível em: https://gallica.bnf.fr/ark:/12148/bpt6k234962?rk=42918;4. Acesso em: 17 jan. 2019.

CLARK, Christopher; KAISER, Wolfram. (orgs.). Culture wars: secular-catholic conflict in nineteenth-century Europe. Cambridge: Cambridge University Press, 2003.

DECOT, Rolf. Säkularisation der Reichskirche 1803: aspeckte kirchlichen Umbruchs. Mainz, Philipp von Zabern, 2001.

GAUME, Jean-Joseph. Le signe de la croix au XIX siècle. Paris: Bibliothèque Saint Libère, 2006, p. 59. Disponível em: http://jesusmarie.free.fr/mgr_gaume_le_signe_de_la_croix. pdf. Acesso em: 17 jan. 2019.

GREGÓRIO XVI, Papa. Mirari Vos: sobre os principais erros do seu tempo. MONTFORT Associação Cultural. Disponível em:

http://montfort.org.br/old/index.php?secao=documentos\&subsecao=enciclicas\&artigo=mi rarivos. Acesso em: 17 jan. 2019.

GROSS, Michael. B. The war against catholicism: liberalism and the anti-catholic imagination in nineteenth-century Germany. Michigan: The University of Michigan Press, 2011.

HERBERMANN, Charles G. The Catholic Encyclopedia: an international work of reference on the constitution, doctrine, discipline and history of the Catholic Church. New York: Catholic Way Publishing, 2014.

JAEGER, Karin. Die Revolution von 1848 und die Stellung des Katholizismus zur Problem der Revolution. In: HUBER, Wolfgang; SCHWERDTFEBER, Johannes (orgs.). Kirche zwischen Krieg und Friede: studien zur Geschichte der deutschen protestantismus. Stuttgart: Ernst Klett Verlag, 1976.

KOSELLECK, Reinhart. Futuro passado: contribuição à semântica dos tempos históricos. Rio de Janeiro: Contraponto, 2012. 
LAGRÉE, Michel. Religião e tecnologia: a bênção de Prometeu. Bauru (SP): EDUSC, 2012. LILL, Rudolf. Der Kulturkampf in Preußen und im deutschen Reich (bis 1878). JEDIN, Hebert (org.). Handbuch der Kirchengeschichte. Freiburg im Breisgau: Herder, 1973.

LOPES, Ana Patrícia Quaresma. Exposiçōes universais parisienses oitocentistas. Coimbra: FCTUC, 2007.

MATA, Sérgio da. Entre Syllabus e Kulturkampf: revisitando o "reformismo" católico na Minas Gerais do Segundo Reinado. In: CHAVES, Cláudia M.; SILVEIRA, Marco A. (orgs). Território, conflito e identidade. Belo Horizonte: Argvmentvm, 2007.

PLANTIER, Monseigneur. Instruction, lettres pastorales et mandements. Tome 1. Paris: EMM. Renault Libraire, 1867, p. 115. Disponível em:

http://www.liberius.net/livres/Instructions,_lettres_pastorales_et_mandements_de_Mgr_ Plantier_(tome_1)_000000284.pdf. Acesso em: 17 jan. 2019.

PRINTY, Michael. Enlightenment and the creation of German catholicism. Cambridge University Press, 2009.

SANTIROCCHI, Ítalo Domingos. Uma questão de revisão de conceitos: romanização ultramontanismo - reforma. Temporalidades. UFMG, v. 2, n. 2, ago/dez. 2010.

SILVA, Wilson Santana. Correntes ideológicas do século XIX e a religião. Fides Reformata. v. XVIII, n. 2, 2013.

SPERBER, Jonathan. Popular catholicism in nineteenth-century Germany. New Jersey: Princeton University Press 1984.

TERTULIANO, Quintos Florens. Decultu feminarum: on the apparel of women. Disponível em:http://www.documentacatholicaomnia.eu/03d/0160-0220,_Tertullianus,_De_Cultu_ Feminarum_[Schaff],_EN.pdf. Acesso em: 17 jan. 2019.

VEUILLOT, Louis. Le parfum de Rome. Tome 1. Paris: Edité par Gaume Frères et J. Duprey, 1862, p. 26. Disponível em:

https://gallica.bnf.fr/ark:/12148/bpt6k1063362/f1.item.r=pr\%C3\%A9f\%C3\%A9rerais. Acesso em: 17 jan. 2019.

WEBER, Max. The protestant ethic and the spirit of capitalism. New York: Charles Scribner's Sons, 1958. 